endurance load in youths. Journal of Physical Education and Sport, 2019;19:1035-1040. https://doi.org/10.7752/jpes.2019.s3149.

25. Wilmore JH et al. Physiology of sport and exercise. (4 td ed). Human Kinetice, (chapter 6), 2008.

26. Korobeinnikov HV, Kharkovliuk NV. The characteristics of autonomic regulation in persons with different levels of mental work capacity. Fiziolohichnyi zhurnal, 2000;46(1):82-88.

27. Blair SN et al. Is physical activity or physical fitness more important in defining health benefits? Medicine and Science in Sports and Exercise, 2001;33:379-399. PMID: 11427763; https://doi.org/10.1097/00005768-200106001-00007.

28. Pop C, Ciomag V. The Influence of Aerobic Gymnastics on the Students' Body Image. Procedia - Social and Behavioral Sciences, 2014;117:129-135. https://doi.org/10.1016/j.sbspro.2014.08.291.

29. Podstawski R, Żurek P, Clark CC, Ihash F, Kozina Z, Omelan A. Sex-Mediated Differences Among University Students Performing Extreme Physical Activity During the 3-Minute Burpee Test. Polish Journal of Sport and Tourism, 2019;26(2):27-33. https://doi.org/10.2478/pjst-2019-0011.

30. Pogrebniak IM, Kudelko VE, Nagovitsina OP. Effect of improving aerobics classes at the level of flexibility of female students. Pedagogics, Psychology, Medical-biological Problems of Physical Training and Sports, 2013;5:49-52.

31. Karpman VL, Belocerkovsky ZB. Testing is in sporting medicine. Moscow, 1998.

32. Yukhymenko L, Makarchuk M, Korobeynikov G, Korobeynikova L, Imas Y, Kozina Z. Hemodynamic aspects of compensatory reactions of human cardiovascular system in conditions of postural loads. Physiotherapy Quarterly, 2018;26(3):6-12. https://doi.org/10.5114/pq.2018.78373.

DOI 10.31392/NPU-nc.series15.2021.7(138).03 УДК 378.015 .31

\author{
Shtanagey D.V. \\ Graduate Student \\ National University of Ukraine on Physical Education and Sport, Kyiv \\ Korobeynikov G.V. \\ Doctor of Science, Professor \\ National University of Ukraine on Physical Education and Sport, Kyiv \\ Kolumbet A.N. \\ Doctor of Science, Professor \\ Kiev National University of Technologies and Design, Kyiv \\ Dudorova L.Y. \\ Doctor of Science, Professor \\ Kiev National University of Technologies and Design, Kyiv
}

\title{
THE STUDY OF THE DYNAMIC CHARACTERISTICS OF HAND MOVEMENTS OF FEMALE BOXERS WITH DIFFERENT TYPES OF FUNCTIONAL ASYMMETRY
}

Purpose: determining peculiarities of speed characteristics of hand movements of female boxers with different functional asymmetry types during dynamic work performance. Material: 50 highly skilled female boxers (masters of sports of international class, masters of sports). The study of female boxer psychomotor functions was designed according to a certain scheme. The motor component of motor response was examined by means of tapping test. The time of a simple and two complex visual-motor responses was determined. The study was completed by determining the identification time for visual stimuli of various degrees of complexity without a motor response. It was assumed that this will allow to consider the visual-gnostic component in a "pure" form. Such a design of the study permitted to evaluate the contribution of each component of psychomotor response to the response speed of female boxers with different types of functional hemispheric asymmetry (FHA) profile. Results: For the first time, the psychophysiological indices of female boxers were obtained. Female boxers were conditionally divided into right-handers, lefthanders and ambidexters. The differences of these groups of female athletes in psychophysiological indices were established. Conclusions: In convenient mode, ambidexters perform work at a high rate than right-handers. At that, their right hand is faster than the left. The total number of movements performed by left-handers is greater than that of right-handers and ambidexters (it concerns both hands). The speed characteristics of female boxers with different types of functional asymmetry in accelerated mode are the same. The pace stability of right-handers and left-handers is high, but less than that of ambidexters. Ambidexters who use the righthanded stance are at advantage than right-handers with right-handed stance. Left-handed female athletes perform movements with greater speed than right-handed ones. For right-handed and left-handed female athletes it is more difficult to maintain the optimal pace of the right than the left hand, whereas ambidexters have problems with maintaining the optimal pace of the left hand. Lefthanded female athletes are faster than right-handed ones.

Keywords: boxing, psychophysiology, female boxers, functional asymmetry.

Штанаеей Д.В., Коробейніков Г.В., Колумбет О.М., Дудорова Л.Ю. Дослідження динамічних характеристик рухів рук жінок-боксерів з різними типами функціональної асиметрії. Мета: визначення особливостей швидкісних характеристик рухів рук жінок-боксерів з різними типами функиціональної асиметрії при виконанні динамічної роботи. Учасники: Висококваліфіковані жінки-боксери (майстри спорту міжнародного класу, майстри спорту) у кількості 50 осіб. Дослідження психомоторних функцій жінок-боксерів було побудоване за певною схемою. За допомогою теппінг-тесту досліджувався моторний компонент рухової реакції. Визначався час простої та двох складних зорово-моторних реакцій. Дослідження завершувалося визначенням часу упізнання зорових стимулів різної міри 
складності без рухової реакції. Передбачалося, що це дасть можливість розглянути компонент зорово-гностики у "чистому" вигляді. Така побудова дослідження давала можливість оцінити вклад кожного компонента психомоторної реакції у швидкість реагування жінок-боксерів з різними типами профрілю функціональної міжпівкульної асиметрії (ФМА). Результати: Уперше отримані психофізіологічні показники жінок-боксерів. Жінки-боксери умовно розділені на правшів, лівшів і амбідекстрів. Встановлені відмінності цих груп спортсменок за психофрізіологічними показниками. Висновки: $B$ зручному режимі амбідекстри виконують роботу з більшою швидкістю, ніж правші. При цьому їх права рука швидша, ніж ліва. Загальна кількість рухів, які зроблені лівшами, більше, ніж у правшів і амбідекстрів (як на правій, так і на лівій руці). Швидкісні характеристики жінок-боксерів з різними типами функціональної асиметрії в прискореному режимі $\epsilon$ однаковими. Стійкість темпу у правшів і лівшів висока, але гірше, ніж у амбідекстрів. Амбідекстри, які використовують праву стійку, знаходяться у більш виграшному положенні у порівнянні з правшами з правосторонньою стійкою. Ліворукі спортсменки виконують рухи з більшою швидкістю, ніж праворукі. Утримання оптимального темпу у правшів і лівшів гірше на правій руці, ніж на лівій. Утримання оптимального темпу у амбідекстрів гірше на лівій руці. Ліворукі спортсменки є швидкіснішими, ніж праворукі.

Ключові слова бокс, психофізіологія, жінки-боксери, функціональна асиметрія.

Introduction. The increase in the level of achievements in modern sport places high demands on the development of qualities and capacities determining the success of sports activity. The significance of various qualities in specific sports events is different. Specific qualities acquire paramount importance in each sports event $[2,9,47]$. The success of the main competitive exercise depends on the level of development of specific qualities. The leading role belongs to psychophysiological indices: sensorimotor responses, operational thinking, and attention properties [7]. Psychophysiological indices form the tactical abilities of athletes and determine the efficiency of athletic fight in changing bout situations [14, 37].

In boxing, there is every opportunity for successful manifestation of a wide variety of mental and physical qualities. Each athlete has an original combination of psychophysiological properties that are decisive in the formation of an individual manner of fight conducting $[13,24,38]$.

The improvement of technico-tactical skills in boxing is due to the use of actions in situations requiring manifestation of varieties of motor response, options of readiness to realize intentions. The success of competitive fight conducting is conditioned by a wide complex of individual typological properties of the body of athletes [6,30,42]. Efficient execution of most of the combat actions is associated with high levels of motor qualities of boxers. For the diagnosis of sports capacities, it is important to have comprehensive information about the composition of competitive activity operations. One should know the boxer's physical fitness level, take into account her psychomotor system individual peculiarities[29, 31].

Human psychomotor apparatus is a complex functional system consisting of sensory, motor and cognitive-intellectual subsystems for controlling complex motor activity.

Success of engagement in a specific sports event corresponds to a particular type of individual asymmetry profile [23, 35, 43]. This is associated with the natural selection of individuals. Attempts to regulate congenital asymmetries may lead to a delay in the growth of sports performance due to negative transfer of motor skill and irrational use of the time limit [12, 41]. The probability of reorientating apparent right-handed and left-handed people to another lateral dominant is small as compared to ambidexters. This is important in terms of choosing a planning strategy and organizing the training process in various sports events. Changing the functional asymmetry to the opposite under conditions of acute adaptation leads to its increase in the process of long-term adaptation [10, 27, 45]. Increase in the initial asymmetry under conditions of acute adaptation results in physical development symmetry during long-term adaptation.

The study of functional asymmetry types as a factor that determines various aspects of sports activity is promising.

The study of functional asymmetry in boxing is of great importance for identifying prerequisites, which determine the peculiarities of motor development, mental and physical state of boxers. It is also important for individualizing the process of athletes' preparation $[4,20,34]$.

The study of functional asymmetry in athletes was conducted in fencing, wrestling and men's boxing. It has not been conducted in female boxers.

Objective - determining peculiarities of speed characteristics of hand movements of female boxers with different functional asymmetry types during dynamic work performance.

Materials and methods. Participants. 50 highly skilled female boxers (masters of sports of international class, masters of sports, candidate masters of sports) served as the subjects. Testing was carried out individually.

Organization of study. The study of female boxer psychomotor functions was designed according to a certain scheme. The motor component of motor response was initially examined by means of tapping test. It was assumed that the lack of visual stimulus in the given test will allow to consider this component in a "pure" form. Then the time of a simple and two complex visual-motor responses was determined. This allowed to assess the response specifics in the "eye-hand" system, depending on visual impact complexity. The study was completed by determining the identification time for visual stimuli of various degrees of complexity without a motor response. It was assumed that this will allow to consider the visual-gnostic component in a "pure" form. Such a design of the study made it possible to assess the contribution of each component of psychomotor response to the response speed of female boxers with different types of functional hemispheric asymmetry (FHA) profile.

Statistical analysis. During experimental data processing, we determined the average values of indices and their errors (X $\pm \mathrm{m}$ ), the degree of difference of averages and the significance of differences (t, $p)$, the dispersion value of variants around the average $(\sigma, C V)$ as well as the degree of relationship between the studied parameters $(r)$.

While conducting complex pedagogical, biomechanical and biological surveys with the participation of athletes, the legislation of Ukraine on health care, the 2000 Helsinki Declaration, Directive No. 86/609 of the European Society regarding people's 
participation in biomedical research were adhered to.

Results. Testing the total number of movements performed by subjects in 2 minutes of work is presented below.

When working in convenient mode, right-handers have no difference in the number of movements performed by the right and left hands (Table 1).

Table 1

Number of movements performed by female boxers in 2 minutes of work at optimal pace

\begin{tabular}{|c|c|c|c|}
\hline Type asymmetry & Right hand & Left hand & $\mathrm{P}$ \\
\hline Right-handers & $379 \pm 10$ & $381 \pm 12$ & $>0.05$ \\
\hline Ambidexters & $472 \pm 14$ & $442 \pm 15$ & $<0.05$ \\
\hline Left-handers & $483 \pm 13$ & $464 \pm 11$ & $<0.05$ \\
\hline
\end{tabular}

Ambidexters perform more right than left hand movements (30 punches more on the average, $p<0.05)$. In general, the number of movements performed by ambidexters is greater than that made by right-handers by both hands (ambidexters and righthanders made 472 and 379 right hand movements and 442 and 381 left hand movements, respectively). In convenient mode, ambidexters perform work faster than right-handers, with their right hand faster than their left.

In left-handers, the right hand also performs significantly more movements than the left (483 and 464 movements, respectively). However, this difference is not as pronounced as that of ambidexters. The total number of movements made by lefthanders is greater than that of right-handers and ambidexters (both hands).

Work in accelerated mode. Significant difference in the number of movements performed by both hands is observed in both right-handers and ambidexters (Table 2). The former performed on the average $618 \pm 24$ and $571 \pm 22$ right and left hand movements, respectively, whereas in the latter these indices constituted $632 \pm 23$ and $589 \pm 28$ movements, respectively. This difference is also observed in left-handers, although it does not reach the level of significance - $639 \pm 23$ and $618 \pm 21$ movements. Therefore, on the average, the right hand in about two minutes of work at an accelerated pace performs approximately 20-50 punches more than the left, regardless of the lateralization type. Significant differences between the number of the right hand movements performed by right-handers, ambidexters and left-handers are not found. The speed characteristics of female boxers with different types of functional asymmetry are similar in accelerated mode.

Table 2

Number of movements performed by female boxers in 2 minutes of work at maximal pace

\begin{tabular}{|c|c|c|c|}
\hline Type asymmetry & Right hand & Left hand & $\mathrm{P}$ \\
\hline Right-handers & $618 \pm 24$ & $571 \pm 22$ & $<0.05$ \\
\hline Ambidexters & $632 \pm 26$ & $589 \pm 28$ & $<0.05$ \\
\hline Left-handers & $639 \pm 23$ & $618 \pm 21$ & $>0.05$ \\
\hline
\end{tabular}

Dynamics of the number of movements made by subjects in every 10 seconds of work.

In the group of right-handers during the first $10 \mathrm{~s}$ the number of movements performed with both hands almost coincides. Within 2 minutes of work, this situation is generally maintained: the difference between the number of movements in every $10 \mathrm{~s}$ does not exceed 2 punches. However, the instability of the dominant hand pace is greater than that of the non-dominant: the drop in speed to the end is more on the right hand (the difference between the maximum and minimum number of movements constitutes 4 punches).

During the first $10 \mathrm{~s}$ the number of the left hand movements in ambidexters slightly exceeds that of the right hand. In the time following, the speed of movements on the left hand decreases (the difference between the maximum and minimum number of movements constitutes 10 punches, $p<0.05$ ), whereas on the right - it retains its initial level in the whole.

In left-handers, during the first $10 \mathrm{~s}$ the number of movements made with both hands is almost the same. This situation persists for quite a long time. Only towards the end of the work, the pace of both hands decreases.

A comparative analysis of the number of the right hand movements shows the highest speed in left-handers while working in the optimal mode. Moreover, it is significantly higher than that of right-handers by 10 punches $(p<0.05)$. In ambidexters, speed indices are slightly lower than in left-handers only at the initial stage of work. After 40 seconds of work, their indices become the same due to decrease in the speed of work of left-handers. This ratio between all three groups is maintained throughout the entire time of work. The pace stability of right-handers and left-handers is less than that of ambidexters.

As concerns the speed of the left hand of female athletes while working in optimal mode, the picture is more diverse. In right-handers, the left hand works at a lower speed as compared to left-handers and ambidexters. This difference is significant (in right-handers, 32 punches are recorded during the first $10 \mathrm{~s}$, whereas in ambidexters and left-handers 42 and 41 , respectively). Throughout the entire time of work, the speed of the left hand in the right-handers practically does not change.

At the initial stage of work, the number of left hand punches in ambidexters and left-handers is almost the same. There is a tendency for a work pace decrease in ambidexters. After $20 \mathrm{~s}$ of work, the curves that reflect the hand movement dynamics of ambidexters and left-handers diverge. For some time this divergence is not very large. Due to gradual decrease in speed of lefthanders, these curves converge again after one and a half minutes of work. Immediately after that, the speed of work of the ambidexters decreases noticeably. At the end of work, the speed indices of the left hand of the ambidexters become almost the same as those of the right-handers.

Number of movements and their dynamics during maximum pace of work.

No difference is observed in the number of movements performed by the right and left hands of right-handers during the first $10 \mathrm{~s}$. The pace of both hands decreases within $2 \mathrm{~min}$ of work. This decrease is especially noticeable during the first $40 \mathrm{~s}$ (in the right hand by 7 punches, in the left by 9 punches). After 40 seconds, the pace of both hands stabilizes for a while. 20 seconds before the end of the work it begins to decline again. The total decrease of the pace of the right and the left hands constituted 9 and 13 punches, respectively. If at the beginning of the work there was no difference between the hands, then towards the end the right 
hand began to exceed the left by 5 punches.

No difference in hand speed of ambidexters is noted in the first $10 \mathrm{~s}$. The pace of both hands tends to decrease during the first $20 \mathrm{~s}$ of work. Then the right hand begins to accelerate returning to initial level for some time, but gradually decreases again reaching the level of the left hand in one minute. At that time, the pace of the left hand stabilizes for a whole minute. At the end of work, the pace of both hands decreases even more. The total decrease of the pace of the right and the left hands in 2 minutes constituted 6 and 9 punches, respectively.

The pace of both hands of left-handers is quite similar during the first $10 \mathrm{~s}$. Then, that of the right hand begins to decrease reaching its minimum at the $20 \mathrm{~s}$ of work. After that, it tends to vary generally remaining at the same level until the very end of the work. The pace of the left hand does not change in the first $20 \mathrm{~s}$. After that, its decline begins, which lasts up to $40 \mathrm{~s}$ of work. Then the pace stabilizes for a while. In the end, it drops again. The total decrease of the right and left hand pace constituted 4 and 9 punches, respectively.

A comparative analysis of the work of each hand indicates that, at a convenient pace, the right hand of ambidexters and left-handers works faster than the left, whereas in right-handers both hands work the same. During maximum pace of work, the right hand works faster in right-handers and ambidexters, whereas in left-handers, differences are present, but are not statistically significant. For right-handers and left-handers it is more difficult to maintain the pace of the right hand, whereas ambidexters experience difficulties with keeping the pace of the left hand. All groups better maintain maximum pace of the right hand than the left.

To determine association between the asymmetry of different systems and the speed of hand movements during the tapping test, an analysis of the representation of the asymmetry of the arms, legs, and vision in the groups of female boxers with a fast and slow convenient and maximum pace was made. For this purpose, all subjects were divided into two groups: one group with a higher speed of optimal rate and the other with a lower speed. A comparison of these groups showed the following.

The group of high speed of performing movements at an optimal pace of work included $77.7 \%$ of left-handed, $50 \%$ of ambidexters and only $25 \%$ of right-handed (Table 3). Temporal parameters of the optimal pace speed are associated with manual lateralization: left-handed athletes perform movements at a higher speed than right-handed ones $(p<0.05)$.

Table 3

Representation of different types of manual asymmetry in groups with different speed of work convenient pace

\begin{tabular}{|c|c|c|}
\hline Asymmetry type & High speed group, $\%$ & Low speed group, $\%$ \\
\hline Right-handed & 25.0 & 75.0 \\
\hline Ambidexters & 50.0 & 50.0 \\
\hline Left-handed & 77.7 & 22.2 \\
\hline
\end{tabular}

The group with a high speed of optimal pace included half of the right-footed (46.6\%), half of the isopods (50.0\%) and $75.0 \%$ of the left-legged ones (Table 4). However, the small number of left-legged in the study group does not allow the association between the leg asymmetry and the speed of the optimal pace to reach a significant level.

Table 4

Representation of different types of leg asymmetry in groups with different speed of work convenient pace

\begin{tabular}{|c|c|c|}
\hline Asymmetry type & High speed group, $\%$ & Low speed group, $\%$ \\
\hline Right-legged & 46.6 & 53.3 \\
\hline Isopodans & 50.0 & 50.0 \\
\hline Left-legged & 75.0 & 25.0 \\
\hline
\end{tabular}

Visual asymmetry does not affect the speed of work during the tapping test. Temporal parameters of the motor action are significantly associated only with hand lateralization $(p<0.05)$ : the left-handed subjects are faster than the right-handed ones.

Discussion. The difference between the total number of movements performed by the subjects in the convenient and maximum modes indicates that this "effect" is more expressed in right-handers than in ambidexters and left-handers. It is however, premature to speak about a greater degree of arbitrary regulation among right-handers on the basis of this fact alone. Such a statement would be justifiable if the initial indices in all groups were the same, and the final ones (the number of movements at the maximum pace) were different. However, we observed quite the opposite picture. It is not unlikely that the accelerated pace that the subjects demonstrate is the maximum possible. We assume that it cannot further increase. The lower value of the "acceleration effect" in ambidexters and left-handers may be due precisely to the fact that they cannot overcome this physiological barrier. This is confirmed by the fact that in ambidexters and left-handers the "acceleration effect" of the right hand is almost the same [11, 21, 33, 40]. In this case, we cannot speak of less arbitrary regulation of movements in ambidexters and left-handers [8, 17].

We suppose that female boxers-ambidexters using the right-handed stance are more advantageous than right-handers who use the same stance. Their dominant hand either exceeds or is equal in speed to the opponent's hand, but not inferior to it. The same applies to the stability of the pace of its work. For right-handers, the picture is less favorable. They can only be equal to or inferior to the opponent-ambidexter [5, 19, 36].

The right hand of right-handers and left-handers maintains the pace of optimal performance worse than that of ambidexters. The left hand of right-handers and left-handers keeps the pace better than that of ambidexters [16, 28, 46].

Neither right-handers, nor ambidexters, nor left-handers maintain a maximum pace for 2 minutes, in all of them it decreases by the end of the work [26]. Moreover, in all groups, the stability of the right hand pace is higher than that of the left. Comparison of the right hand work of the subjects reveals that the highest pace decrease occurs in the right hand of the righthanders, whereas the lowest - in left-handers. The highest pace decrease is also observed in right-handers, whereas in ambidexters and left-handers it is the same. Both hands of right-handers maintain the pace of work worst of all. Regardless of the lateralization type, the pace stability of the right hand is higher than that of the left $[3,18,32]$.

There are certain differences in the petrformance of the tapping test between right-handers, left-handers and ambidexters $[15,22]$. The difference in speed of movements is determined by the initially selected pace of activity. If the pace is the most 
convenient, then in this case the ambidexters and left-handers outstrip the right-handers in speed. If the maximum pace is set, then there are no differences in speed between the groups [1, 25, 44]. Maximum pace is beter maintained by the left-handers and the worst of all by the right-handers.

It is impossible to draw firm conclusions based on the data obtained. Presented results bring forth a problem only, but do not solve it. Further diversified and in-depth study of this aspect is required. The findings may be used as a data box for creating complex motor portraits of representatives of various types of functional asymmetry and their using in the choice of a right-handed or left-handed stance.

Conclusions 1. In convenient mode, ambidexters tend to perform the work faster than right-handers. At the same time, their right hand is faster than the left. 2. The total number of movements made by left-handers is greater than that of right-handers and ambidexters (both hands). 3. The speed characteristics of female boxers with different types of functional asymmetry are the same in accelerated mode. 4. The pace stability of right-handers and left-handers is high, but worse than that of ambidexters.

5. Female boxers-ambidexters who use the right-handed stance are more advantageous than right-handers preferring the same stance. 6. Left-handed athletes perform movements with higher speed than right-handed ones. 7. Optimal pace maintenance in right-handers and left-handers is worse on the right hand than on the left. Maintaining the optimal pace in ambidextras is worse on the left hand. 8. Left-handed athletes are faster than right-handed ones. Funding. The author received no financial support for the research, authorship and publication of this article.

Conflict of interest. The authors declare that there is no conflict of interests.

\section{References} (in Russian)

1.Akopyan, A.O. (2017). Reactions to predict attacking actions in boxing. Teoriya i Praktika Fizicheskoy Kul'turi, 2, 17-19.

2.Akopyan, A.O., Kulagina, L.A. (2010). Optimization of the functional state of highly skilled athletes edinobortcev management-based psycho-emotional state at the stages of centralized training. Vestnik Sportivnoy Nauki, 1, 3-8. (in Russian)

3.Akopyan, A.O., Kulagina, L.A. (2016). Anticipation reactions in boxing. Vestnik Sportivnoy Nauki, 6, 3-7. (in Russian)

4.Aksutin, V.V., Korobeynikov, G.V. (2014). Psychophysiological states and special performance of boxers with different styles of fight. Pedagogics, Psychology, Medical-Biological Problems of Physical Training and Sports, 12, 3-6.

5.Aksutin, V.V., Korobeynikov, G.V. (2014). Study of special capacity in boxers with different styles of fight. Physical Education of Students, 5, 3-7.

6.Berdychevskaya, E.M., Gronskaya, A.S. (2009). Functional asymmetries and sport: a manual on a functional interhemispheric asymmetry. Scientific world, 647-691.

7.Berdychevskaya, E.M., Gronskaya, A.S., Bugaetsc, J.E., Khachaturova, I.E. (2007). Functional asymmetries at providing of effective activity in sport. Journal of Asymmetry, 1, 1, 62-64.

8.Berdychevskaya, E.M., Gronskaya, A.S., Cherenkevich, V.I. (2008). Typological proper-ties of the nervous system and functional asymmetry of boys boxers. Physical Rducation, Sport Science and Practice, 1, 33-35.

9.Bleer, A.N. (2006). Psychological factors of sustainability of psychomotor actions in the martial arts. Theory and Practice of Physical Culture, 6, 28-31. (in Russian)

10. Bugayets, Y.E., Gronskaya, A.S., Maluka, M.V. (2018). Features of anxiety manifestation in skiers with different individual asymmetry profile. Bulletin of Psychophysiology, 1, 96-99.

11. Chadli, S., Ababou, N., Ababou, A. (2014). A new instrument for punch analysis in boxing. Procedia Engineering, 72 , 411-416.

12. Chen, Y.C., Tseng, T.C., Hung, T.H., Hsieh, C.C, Chen, F.C., Stoffregen, T.A. (2013). Cognitive and postural precursors of motion sickness in adolescent boxers. Gait \& Posture, 38(4), 795-799.

13. Chernozub, A., Danylchenko, S., Imas, Y., Kochina, M., Natalia, I., Korobeynikov, G., Gorashchenco, A. (2019). Peculiarities of Correcting Load Parameters in Power Training of Mixed Martial Arts Athletes. Journal of Physical Education and Sport, 19, 481-488.

14. Favre, J., Mass, Y., Aminian, K. (2007). Study of punches performance in boxers with inertial sensors. Journal of Biomechanics, 40, 530 .

15. Filimonov, V.I. (2009). Sovremennaia sistema podgotovki bokserov [Modern system of preparation of boxers]. INCAH.

16. Golomazov, S.V., Chirva, B.G. (2003). Anticipation of the goalkeeper in the game and assessing his abilities to successfully carry out the action. Theory and Methodology of Football, 4 (20), 13-18.

17. Gorbachev, S.S. (2007). Psychological and physiological states of boxers in different after the extreme situations of training and competition activity. Theory and practice of physical culture, 5, 44-45.

18. Gronskaja, A.S., Cherenkevich, V.I. (2005). Individual profile of asymmetry and feature of brief memory of youths of boxers. Scientific works of I of convention of physiologists of the CIS. 2, 298.

19. Kessler, J., Smith, M. (2008). Boxing psychology - why fights are won and lost in the head. Journal of Shenyang Institute of Physical Education, 27(2), 53-58.

20. Khusiajnov, Z.M. (2007). Osobennosti proiavleniia udarnoj massy pri nanesenii udarov v bokse. Taktiko-tekhnicheskie kharakteristiki poedinka $v$ sportivnykh iedinoborstvakh [Peculiarities of manifestation of shock mass in hitting boxing. Tactical and technical performance characteristics of the fight in combat sports]. Moscow, Physical culture and sports, 200-210.

21. Kiprych, S.V. (2014). Control system improvement of qualified boxers based assessment system change reaction cardiorespiratory during the immediate preparation for competition. Physical Education of Students, 4, 26-31.

22. Kiprich, S.B., Berinchik, D.Y. (2015). Specific descriptions of functional providing of the special endurance of boxers. Pedagogics, Psychology, Medical-Biological Problems of Physical Training and Sports, 3, 20-27. 
23. Kiprych, S.V., Donets, A.V., Makhdi, Omar Ali. (2013). Improvement of management by training process of boxers at a stage of direct preparation for competitions. Physical Education of Students, 6, 20-24.

24. Kiselev, V.A. (2006). Improvement of sports training of skilled boxers. Moscow: Physical Culture, 127 p.

25. Kolesnik, I.S., Osipov, D.A. (2013). Factors affecting the increase in the level of technical readiness of the qualified boxers. Pedagogiko-psikhologicheskie i mediko-biologicheskie problemy fizicheskoj kul'tury i sporta, 26, 1, 79-87.

26. Kolumbet, A.N., Dudorova, L.Y., Dovgych, A.A., Ivaschenko, E.A., Melnik, A.A., Nichiporenko, I.V., Suprunenko, M.V. (2019). The correction of cyclists pedalling techniques by means of teaching guidelines. Journal of Physical Education and Sport, 19 (2), 151, 1048-1052. ISSN: 2247-806X; p-ISSN: 2247-8051; ISSN-L=2247-8051. DOI:10.7752/jpes.2019.02151.

27. Korobeynikov, G., Korobeynikova, L., Potop, V., Nikonorov, D., Semenenko, V., Dakal, N., Mischuk, D. (2018). Heart rate variability system in elite athletes with different levels of stress resistance. Journal of Physical Education and Sport, 18(2), 550554. doi:10.7752/jpes.2018.02079.

28. Korobeynikov, G., Glazyrin, I., Potop, V., Archipenko, V., Glazyrina, V., Dudnyk, O., \& Dakal, N. (2019). Adaptation to endurance load in youths. Journal of Physical Education and Sport, 19(3), 1035-1040. doi:10.7752/jpes.2019.s3149.

29. Korobeynikova, L.G., Makarchuk, M.Y., Korobeynikov, G.V., Mischenko, V.S., Zapovitryana, O.B. (2016). States of psychophysiological functions of elite athletes in different aging groups. Fiziolohichnyi zhurnal, 62(6), 81-87.

30. Korobeynikov, G., Potop, V., Korobeynikova, L., Kolumbet, A., Khmelnitska, I., Shtanagey, D., Goletc, A. (2019). Research of the hand motion dynamic characteristics of the women boxers with different types of functional asymmetry. Journal of Physical Education and Sport, 19, 2185-2191. doi:10.7752/jpes.2019.s6328

31. Kozina, Z., lermakov, S., Cretu, M., Kadutskaya, L., Sobyanin, F. (2017). Physiological and subjective indicators of reaction to physical load of female basketball players with different game roles. Journal of Physical Education and Sport, 17, 378382.

32. Kozina, Z., Prusik, K., Görner, K., Sobko, I., Repko, O., Bazilyuk, T., Korol, S. (2017). Comparative characteristics of psychophysiological indicators in the representatives of cyclic and game sports. Journal of Physical Education and Sport, 17(2), 648655. doi:10.7752/jpes.2017.02097.

33. Larson, N.C., Sherlin, L., Talley, C., Gervais, M. (2012). Integrative Approach to High-Performance Evaluation and Training: Illustrative Data of a Professional Boxer. Journal of Neurotherapy, 16(4), 285-292.

34. Malazonia, I.G., Gronskaya A.S. (2016). Features of asymmetric actions of boxers of different motor phenotype in changing kinematic situations. Pedagogical-Psychological and Medico-Biological Problems of Physical Culture and Sports. 11, 4, 217-224.

35. Martsiv, V.P. (2014). Comparative analysis of competitive activity parameters of amateur boxers high qualification. Physical Education of Students, 6, 41-44.

36. Ostyanov, V.N. (2011). Obuchenie i trenirovka bokserov [Educating and training of boxers]. Kiev, Olympic Literature.

37. Ouergui, I., Hammouda, O., Chtourou, H., Gmada, N., Franchini, E. (2014). Effects of recovery type after a kickboxing matchon blood lactate and performance in anaerobic tests. Asian Journal of Sports Medicine, 5, 2, 99-107.

38. Podrigalo, L., lermakov, S., Potop, V. et al. (2017). Special aspects of psycho-physiological reactions of different skillfulness athletes, practicing martial arts. Journal of Physical Education and Sport, 17, 2, 519-526.

39. Podrigalo, L.V., Volodchenko, A.A., Rovnaya, O.A., Ruban, L., Sokol, K. (2017). Analysis of adaptation potentials of kickboxers' cardio-vascular system. Pedagogics, Psychology, Medical-Biological Problems of Physical Training and Sports, 21, 4, $185-191$.

40. Pavelec, O.J., Ostyanov, V.N., Maydanyuk, O.V. (2013). Model features as the basis of preparation of boxers individualization principal level (elite). Pedagogics, psychology, medical-biological problems of physical training and sports, 10, 4649.

41. Platonov, V.N., Bulatova, M.M., Kosminina, E.S. (2012). Feminism and program of the Olympic games. A culture is physical and health, 3(39), 12-19.

42. Rodionov, A.V. (2001). Principles of Psychological and physiological interface in preparation of sportsmens-fighters of high qualification. Theory and practice of physical culture, 11, 34-36.

43. Savchin, M.P. (2013). A dynamics of the special capacity of boxer of collapsible command of Ukraine in the last olympic loop. Nauka v olimpijskom sporte, 2, 55-63.

44. Sybil, M., Pervachuk, R., Zahura, F., Stelmakh, Y., \& Bodnar, I. (2018). Considering the current balance between lactate and alactate mechanisms of energy supply in preparation of free style wrestlers. Journal of Physical Education and Sport, 18, 1826-1830. doi:10.7752/jpes.2018.s4267.

45. Syshko, D.V., Kroviakov, V.F., Savina, K.D., Syshko, G.D. (2011). Osobennosti reguliacii serdechnogo ritma bokserov razlichnoj kvalifikacii [Specific features of regulation of heart beats of different qualification boxers]. Physical Education of Students, 6, 96-98.

46. Taymazov, V.A., Golub, Ya.V. (2004). Psychophysiological state of an athlete: methods of evaluation and correction. SPb.: Olimp SPb. 400 p.

47. Zubac, D., Simunic, B., Karnincic, H. et al., (2017). Skeletal muscle contraction time is an important factor in the muscle damage response in kickboxing athletes. Archives of Budo, 13, 169-178. 